\title{
THE FEASIBILITY OF IMPLEMENTATION OF RECRUITMENT AND SELECTION TECHNIQUES IN A CIVIL CONSTRUCTION COMPANY MANAUS - AM
}

\section{Valquiria Delani Alves Dias ${ }^{1}$, David Barbosa de Alencar ${ }^{2}$, Fábio Soares de Oliveira ${ }^{3}$, Maria Cristiane Bandeira Santos ${ }^{4}$, Camily Murrieta Vasconcelos Oliveira Bezerra ${ }^{5}$ and Igor Felipe Oliveira Bezerra ${ }^{6}$}

\author{
1, 2, 3,4 Braulo Cardoso de Mattos Higher Education Institute - FASERRA. Manaus-Amazonas, Brazil. \\ ${ }^{5,6}$ Nilton Lins University. Manaus-Amazonas, Brazil.
}

Email: valquiria.delani7@email.com, david002870@hotmail.com, fbsoares171@gmail.com, cristiane.engenheiracivil@gmail.com, camilymv@ hotmail.com, igor.bezerra@uniniltonlins.edu.br

Received: Aug $27^{\text {th }}, 2019$

Accepted: Aug 30th 2019

Published: December 02 ${ }^{\text {th }}, 2019$

Copyright @ 02016 by authors and Galileo Institute of Technology and Education of the Amazon (ITEGAM).

This work is licensed under the Creative Commons Attribution International License (CC BY 4.0).

https://creativecommons.org/licen ses/by/4.0/

\begin{abstract}
Recruiting a recruitment and selection that points the interests of companies and values the process with feedback directed to the candidate is the new practice of many companies seeking to reach the human side. The aim of this study is to discuss the importance of the Recruitment and Internal Selection process in the P\&S Enterprise by using a case study as a research method to analyses the organizational results. In this way, it is concluded that the company correctly uses its career plan, giving due importance to the institution's recruitment and internal selection process. In order to enhance the knowledge of the managers who act in this process of employee review, the company could provide specific courses for their managers when they will enhance their knowledge in planning, recruiting and empowering the individual to suit the organization's organizational system.
\end{abstract}

Keywords: Recruitment; Process; Selection of people.

\section{INTRODUTION}

A company that selects candidates using the recruitment and personnel selection tool has been winning for both the company itself and the candidates. According to [1], recruitment is a set of techniques and procedures aimed at attracting potentially qualified candidates capable of holding positions within the organization.

Some institutions find it difficult to fill their staffing needs. These needs, if incorrectly planned, could cause serious problems. Given the above, the objective of this paper is to discuss the importance of the Recruitment and Internal Selection process at P\&S Company, which operates in the Civil Construction branch, being located in the city of Manaus in the State. do Amazonas at Av. Cascavel, 46 - Cidade Nova 01, using a case study as a research method to analyze the organizational results expected by these institutions.

The methodology adopted was based on descriptive research through review, documentary and bibliographical analysis, seeking to systematize the subject developed by other authors in order to achieve the proposed objectives. Regarding the means of investigation, the questionnaire was chosen. This type of research aims to analyze or explain a particular problem in the light of the existing theoretical framework. In order to improve the knowledge of managers working in this process of employee analysis.

\section{BIBLIOGRAPHIC REFERENCE}

Recruitment is the set of procedures aimed at attracting potentially qualified candidates able to fill positions within the organization [2]. It is through the recruitment and selection process that the manager can effectively verify if or not an applicant has the profile needed to fill a job opening in the company.

We also emphasize that it is a constant challenge for companies to get candidates for vacancies. Hiring qualified people requires the organization to have a large number of potential employees in order to be able to choose the best one [3].

There are three types of recruitment: internal, external and mixed. [4] argues that: 
Internal recruitment is used to fill vacancies by relocating existing staff in the organization. "As its name implies, internal recruitment seeks candidates for the existing job within the company. To be successful in this process, the integration of the manager with the other sectors as well as intense and continuous communication between the areas are fundamental factors" [5].

This is not a common practice in all companies, many claimthat internal recruitment creates competition among employees, frustrating those who have not been selected. But there is also a positive side to professional career development for employees, "taking advantage of company staff has the following advantages: it motivates all employees, signaling the willingness to promote the "silver of the house "and create career prospects" [6].

External recruitment is used to attract candidates who are outside the institution, i.e. it is the search for professionals not linked to the company directly or indirectly, either in the job market from some specific sources, for example, state or private employment agency. . The advantages of external recruitment are lower than internal recruitment, because the cost of outsourcing logistics is much more costly for the organization, but one must take into account the context in which the company is currently located is not always possible. find what you are looking for within the organization.

External recruitment seeks potential candidates to fill existing vacancies through external means such as: posters, advertisements, employment agencies, among others [7]. The organization's people manager is responsible for filling vacancies always looking for a better profile and so that organization can save resources and improve results.

However, external recruitment can discourage company employees who, when filling a vacancy, seek recognition and career path. In certain situations, there is no way to place an internal contributor when desired profile is not found.

Mixed recruitment can be adopted in three system alternatives [8]:

I. External recruitment, followed by internal recruitment, if it does not yield desirable results;

II. Internal Recruitment, followed by External Recruitment, the organization prioritizes its employees in disputing existing opportunities; and,

III. External recruitment and internal recruitment, concomitantly, is the case when the organization is most concerned with filling an existing vacancy. Staff recruitment consists of a set of technical and administrative procedures designed to attract potentially qualified candidates who are able to fill existing or future positions within an organization. This search is not randomized, but is based on personnel requirements, taking into account the selection criteria adopted by the organization's personnel policies. To be effective, recruitment must attract a contingent of people large enough to adequately supply the selection process, in which the competitor's knowledge, skills and attitudes that compete with each other in terms of qualifications are assessed. This is because the larger the number of candidates, the greater the probability of success of the selection process [9].

Recruitment sources are the areas of the human resources market that are exploited by human resource capture mechanisms. In other words, the human resources market has diverse sources of candidates that must be diagnosed and localized by the influencing organization through a variety of fundraising techniques to attract human resources to meet their needs.

In his work [10] he points out that the sources of human resources capture are configured in places where, potentially, the recruiter can find the professionals that the organization needs. These recruitment sources can be classified as internal or external.
Internal sources - Under this heading are grouped the human resources that make up the organization's staff. This is in principle the closest source and the best data you provide about the professional you are looking for. Through the results obtained in the different types of evaluations to which the organization's staff was submitted, it is possible to detect the performance of each one, potentially capable of performing the desired function, and forward to the selection sector that will appoint the most apt to occupy the organization. Function. Using this type of source for recruitment can offer both advantages and disadvantages, and it is up to the recruiter to know which one is most important and which best suits the organization's interests at the time of recruitment. Internal sources can be advantageous because it is the least expensive, dismissing the work of employment agencies, and stimulating workers to greater organizational commitment and selfdevelopment as they can be promoted (vertical movement), transferred from functions (horizontal movement) or even promoted with transfer (diagonal movement).

External sources - refers specifically to contingents that do not maintain ties with the company. In external recruitment, one can resort to candidates with or without experience, with advantage in both cases. For experienced applicants we can consider the likelihood of increased productivity and security in choosing. With regard to candidates without experience we can consider the possibility of remuneration more compatible with those desired by the organization. As also, the easiest to instill methods and work habits in this worker.

\section{MATERIALS AND METHODS}

In general, this work can be classified as applied research, as it is based on the application of theory already elaborated, i.e., it does not aim to discover theory.

In this paper, we will use the deductive method where [11] state that: the deductive reasoning aims to explain the content of the premises. Through a descending chain of reasoning from general to particular analysis, it comes to a conclusion. It uses syllogism, a logical construct to, from two premises, draw a third logically derived from the first two, called completion.

This study can be considered qualitative because it has no interest in measuring variables, as its objective is related to the understanding and interpretation of the process, and the use of statistics is not necessary.

As for the technical procedures used for the formation of this work, the bibliographic research was used. For [12], the bibliographic research "aims to collect information and prior knowledge about a problem for which an answer is sought or about a hypothesis that one wants to try out" In this research was also applied a questionnaire, which [13] clarifies that: "The survey, in a survey, is an instrument or data collection program. If it is made by the researcher, it is completed by the informant. The language used in the questionnaire should be simple and straightforward for respondents to clearly understand what is being asked. The use of slang is not recommended, unless it is necessary due to the need of language characteristics of the group (surfers' group, for example. Within this perspective the subjects were selected by homogeneity criteria chosen by the researcher, with a closed number of 10 informants, "which resembles simple sampling and should be applied only in cases where it is possible to identify in advance the position of each element in an ordered population" [14]. 


\section{STUDY APPLICATION}

For the execution of the study, the documentary analysis was followed by an interview. Regarding the documentary analysis, it is considered very similar to the bibliographic one. The difference is in the nature of the sources, because this form uses materials that have not yet received analytical treatment, or that can still be reworked according to the research objects.

According to [15], the interviews can be classified as: informal, focused, by agenda and formalized, as listed below:

- Informal Interview: It is the least structured possible and only distinguishes itself from simple conversation because it has as its basic objective the collection of data. It is recommended in exploratory studies, which aim to address realities little known by the researcher, or offer an approximate view of the researched problem;

- Focused interview: is as free as the previous one; However, it focuses on a very specific theme when the interviewee is allowed to speak freely about the subject, but with the interviewer's effort to regain the same focus as he begins to deviate;

- By guidelines: presents a certain degree of structuring, as it is guided by a list of points of interest that the interviewer explores throughout his course. The guidelines must be ordered and have a certain relationship with each other. The interviewer asks few direct questions and lets the interviewee speak freely as he or she reports on marked agendas; and,

- Structured or formalized: develops from a fixed list of questions, whose order and wording remain invariable for all respondents who are usually in large numbers. Because it enables the quantitative treatment of data, this type of interview becomes the most appropriate for the development of social surveys.

In this stage of elaboration and application of the interview about the relevance of training in the Construction Industry (ICC), the exploratory research typology was used, where [12] link to the type of research in which there is little knowledge and literature about the researched theme.

I. Determination of company needs; finally;

II. Preparation and evaluation of the interview; and

III. Application of interview with company manager.

In the first part of the interview elaborated, a deductive analysis was carried out, where [15] describes that it is a method that "starts from principles recognized as true and indisputable and makes it possible to reach conclusions in a purely formal manner, that is, solely by virtue of their logic." The other steps were worked on site.

The author chose not to use very specific questions, always having ethics as a distinguishing factor in the research performance, the questions being neutral in nature, as a way of not inducing the answers.

\section{RESULTS / DISCUSSIONS}

The P\&S Company operates in the Civil Construction Branch is located in the city of Manaus in the State of Amazonas at Av. Cascavel, 46 - Cidade Nova 01, it is seeking to adapt to the changes that the market requires, so that it can achieve its major objective. which is to reduce staff instability, and to decrease the turnover rate that is a problem today, generating considerable losses.

The development of this process in the HR sector is very important, it is known that the return will be low turnover and increased quality in production and final product, generating significant improvements for the company, improving its processes and optimizing its results.

The Company's segment is Civil Construction in which it outsources labor for the Engineering of the same Branch. With an abundant supply market, $\mathrm{P} \& \mathrm{~S}$ seeks to provide quality services with a competitive edge. One of the challenges faced by the company is the recruitment and selection process that through it will hire qualified labor to perform the activities offered by the open position. Recruitment is based on data on the organization's present and future human resource needs.

It is important to note that motivation will generate positive results, if only if applied in a way that can move employees positively. This attention is due to the fact that motivation is a process that requires care in its application, because individuals are different from each other, and each has its own way of being motivated.

Through recruitment and internal selection, employees are selected to occupy a certain position and, according to it, their competencies will be assigned according to each sector, aiming at the company's policies and culture. $P \& S$ has a market differential created to minimize the difficulty of providing executive or managerial positions and specialized technicians in more competitive and cost of living squares.]

Regarding the profile of employees, the following results were obtained:

Table 1: Interview Age Range.

\begin{tabular}{|c|c|c|}
\hline AGE RANGE & QUANT & $\%$ \\
\hline A. 25 to 30 years old & 1 & $10 \%$ \\
\hline B. 31 to 35 years old & 3 & $30 \%$ \\
\hline C. From 37 to 39 years old & 3 & $30 \%$ \\
\hline D. 40 to 45 years old & 2 & $20 \%$ \\
\hline E. Up to 50 years & 1 & $10 \%$ \\
\hline TOTAL & $\mathbf{1 0}$ & $100 \%$ \\
\hline
\end{tabular}

Source: Authors, (2019).

In view of motivation, $P \& S$ favors the acquisition of important knowledge for its professional training as a bricklayer; guiding your professional development, pointing out what are the fundamental knowledge for the functions you want to occupy. Profiles are established to identify employees who have the potential to take on segment roles in relation to professional competencies in the exercise of their duties.

We can see that most of the employees are adults between 26 and 50 years old, that is, still young but "mature" (original emphasis of the authors).

Table 2: Level of School Interviewer.

\begin{tabular}{|l|c|c|}
\hline \multicolumn{1}{|c|}{ DEGREE OF SCHOOL } & QUANT & \% \\
\hline A Illiterate & 0 & $0 \%$ \\
\hline B Incomplete Elementary School & 3 & $30 \%$ \\
\hline C Complete primary education & 2 & $20 \%$ \\
\hline D Incomplete high school & 3 & $30 \%$ \\
\hline E Complete high school & 2 & $20 \%$ \\
\hline TOTAL & $\mathbf{1 0}$ & $\mathbf{1 0 0 \%}$ \\
\hline
\end{tabular}

Source: Authors, (2019). 
These data indicate that there is a huge opportunity in the company that are the workers with low education $(30 \%$ not completed elementary school).

Table 3: Service Time.

\begin{tabular}{|c|c|c|}
\hline CIVIL CONSTRUCTION SERVICE TIME & QUANT & $\%$ \\
\hline A. Up to 3 months & 1 & $10 \%$ \\
\hline B. Less than 05 years & 2 & $20 \%$ \\
\hline C. From 5 to 10 years & 2 & $20 \%$ \\
\hline D. From 10 to 15 yeas & 3 & $30 \%$ \\
\hline E. Over 15 years & 2 & $20 \%$ \\
\hline TOTAL & $\mathbf{1 0}$ & $\mathbf{1 0 0 \%}$ \\
\hline
\end{tabular}

Source: Authors, (2019).

The graph (03) shows us that $30 \%$ of employees work between 10 and 15 years in the construction industry. The measures for making vacancies available are based on the company's People Management proposals, which, in a joint effort with the directors, seek to faithfully translate the wishes of the network's employees, effectively facilitating their work.

Once the main sources of Recruitment have been analyzed, and decided on what is most convenient in the face of what is intended, the recruiter must decide how to achieve it. For this he can use different procedures[9]. In order for staff recruitment to reach its goal, it is important that HR professionals choose well the ways to disclose open positions. In fact, there is no rule about which tool to use in each case, it will all depend on the need of the recruiter. and of the possibilities that a given environment may generate, among the most used we can mention: internet, newspaper, internal and external indications, private employment agencies and public employment agencies.

Private Employment Agencies - These bring to the organization the advantage of a pre-selection of professionals. The organization establishes with the agencies the characteristics and requirements that professionals need to fulfill, and it is then up to them to indicate a list of professionals most suitable for the postulation of the position. Despite the somewhat simplistic placement of the role of employment agencies, the important thing to note is the dispersion of information that causes the organization's indirect contact with the professional. The inclusion of an intermediary in this contact masks sometimes quite significant aspects in the professional organization relationship [9].

Public Employment Agencies - Today, employment agencies have lost ground to human resources consultancies, which have the advantage of making a first selection, although sometimes for business reasons it is poorly judged.

\section{FINAL CONSIDERATIONS}

As we conclude this study, we can see that a few decades ago it was thought that technology could replace man over time. It is in need of more and more capable people.

It is clear that recruitment and its forms guarantee business success and the search for people who are increasingly committed to the organization and who make up the right profile should start at the recruitment stage of the company.

Based on research conducted with P\&S employees, along with the conversation with Personnel Management, we can see that the Internal Recruitment and Company Selection process uses daily tools for job availability and application of its employees, when they have access to information about the vacancy available and can view the positions, their competencies and profile, making the candidates motivate themselves to improve their knowledge and skills to win the vacant position.

The institution follows the vision of aligning its interests with the interests of its employees, thus conducting an internal recruitment process and effective and efficient selection would limit the likelihood of process failure, being the same an organized and effective process.

Analyzing P\&S internal recruitment and selection process, it was observed that $\mathrm{P} \& \mathrm{~S}$ has an external selection process. However, the Company has institutional rules and a structured career plan that aims at the development of its professionals, in the continuous search for the improvement of their skills, knowledge and attitudes.

\section{REFERENCES}

[1] Chiavenato, Idalberto. Administração de vendas. Elsevier, 2010 .

[2] Ferreira, Sidneis Francisco; Soeira, Fernando dos Santos. A importância do recrutamento e seleção de pessoas em uma empresa de pequeno porte do setor de móveis. Revista Eletrônica "Diálogos Acadêmicos, 2013, 10.

[3] Spector, Paul E. Psicologia nas organizações. 2. ed. São Paulo: Editora Saraiva, 2002.

[4] Baylão, André Luis da Silva; Rocha, Ana Paula de Sousa. A importância do processo de recrutamento e seleção de pessoal na organização empresarial. 2014.

[5] Tachizawa, Takeshy; Ferreira, Victor Cláudio Paradela; Fortuna, Antonio Alfredo Mello. Gestão com as pessoas: Uma abordagem aplicada às estratégias de negócios. 2 ed. Rio de Janeiro: Editora FGV, 2001.

[6] Lacombe, Francisco Jose Masset. Recursos Humanos: princípios e tendência. São Paulo. Ed. Saraivas. 2005.

[7] Marras, Jean Pierre. Administração de Recursos Humanos: do operacional ao estratégico. São Paulo. Ed. Futura. $3^{\text {a }}$ ed. 2002.

[8] Ribeiro, Antonio de Lima. Gestão de pessoas. Editora Saraiva, 2017.

[9] De Assis Palharini, Francisco. Recrutamento de Recursos Humanos: fundamentos e tendências. Cadernos do ICHF, 2011, 1.80: $1-24$

[10] Pierantoni, Célia Regina; Varella, Thereza Christina; França, Tania. Recursos humanos e gestão do trabalho em saúde: da teoria para a prática. Observatório de recursos humanos em saúde no Brasil: estudos e análises, 2004, 2: 51-70.

[11] Marconi, Marina de Andrade; Lakatos, Eva Maria. Fundamentos de Metodologia Cientifica - $7^{\circ}$ ed. São Paulo: Atlas, 2010.

[12] Beuren, Ilse Maria (Org.). Como elaborar trabalhos monográficos em contabilidade. 2. ed. São Paulo: Atlas, 2004.

[13] Severino, Antônio Joaquim. Metodologia do trabalho científico. Cortez editora, 2017.

[14] Bello, José Luiz de Paiva. Metodologia Cientifica. 2004.

[15] Gil, Antonio C. Métodos e técnicas em pesquisa social. 6. ed. São Paulo: Atlas, 2008. 